\title{
STRATEGIC ASPECTS OF ECONOMIC SECURITY LEVEL FORMATION AS A PRECONDITION FOR BUILDING SAFETY
}

\section{Stetsenko S. P.}

\section{INTRODUCTION}

Economy is a multi-level system of social relations, where a macro level is the main one. At this level we deal with the functioning of complex large independent economic systems, most of which are national economies. At the micro level we study the functioning of simple homogeneous systems and entities that make up macroeconomic structures. Such entities are economic entities and households. And last but not the least, is the mesolevel, which forms complex subsystems that are components of national economies, such as regions and industries.

Studies of certain aspects of the issue of economic security were considered in the works of leading Ukrainian scientists: L.I. Abalkina, A.I. Arkhipova, O.M. Bandurka, I.Ya. Bogdanova, Z.S. Varnalia, A.S. Galchinsky, V.M. Heyts, O.M. Golovchenko, V.E. Duhova, Ya.A. Zhalila, G.A. Pasternak-Taranushenko, V.L. Tambovtseva, L.S. Shevchenko, M.M. Yermoshenko et al.

In recent years modern economists have paid considerable attention to the notion of economic security for business entities. For construction companies, this concept is little known and poorly understood. Economic safety of construction enterprises is researched in the works of A.F. Goiko, L.V. Sorokina, Fedosova O.V., Molodid O.O., Vakhovich I.V., Migus I.P., Kushniruk A.O. et al.

The main purpose of the article is to study the formation of individual strategic aspects of economic security levels and the prerequisites for creating an economic security system for construction.

\section{Theoretical and practical prerequisites}

for the formation of strategic aspects of economic security as a basis for the development of economic systems

The current stage of the Ukrainian society development, characterized by the search for a paradigm of sustainable socially oriented recovery and growth, is accompanied by a qualitative transformation of the institutional environment, which has its manifestation in the redistribution of property rights and aggravation of contradictions between existing, reformed and 
imported institutions, decentralization trends in regions and industries. Such changes are complicated by the incompleteness of structural transformations, the lack of a holistic concept of long-term state development, the exacerbation of internal and external risk factors for the national security system in the context of intensifying globalization processes. This causes unstable transformational dynamics of key macroeconomic indicators.

Meanwhile it activates the opportunistic behavior of economic agents, which is an attempt to avoid the tax burden, blocking competition in the commodity and financial markets, a way to gain illegal access to budget resources and state property, redistribution of national income, export of capital abroad.

At present, Ukrainian society needs a new scientific paradigm which, in line with the challenges of post-industrial economy in the post-crisis development, will provide a qualitatively new interpretation of the principles of institutional design of the national security system and its attributive element - the system of economic security. The influence of formal and informal institutions on the content and principles of the functioning of the economic security system is characterized by contradiction, as market institutions can act as both a means of providing it and a factor of threats. The nature of the impact is determined by the content of forms and methods of institutional design, and the role of the state in realizing the positive potential of economic security institutions as a source of translational macroeconomic dynamics is of paramount importance, due to its heterogeneity as a result of the contradictions of institutional entities, and forced on mass and rapid import of market institutions. This determines the need to implement a state regulated option of market institutionalization of economic security relations based on the modernization of existing formal and legalization of informal institutions in the process of purposeful institutional design.

Ensuring economic security is crucial enough to formulate a strategy for socio-economic development of Ukraine. The problem of economic security of Ukraine is caused by liberalization of economy and foreign economic activity, globalization of the world economy, processes of regional and sectoral economic integration, formation of mechanisms of cooperation and interaction of Ukraine with other countries of the European Union, as well as factors of international cooperation with highly developed economies. Realities show that these days regions, enterprises, organizations, corporations, individual entrepreneurs become independent participants in foreign economic activity.

The main national interests in building the economic security system are achieved through the following important tasks:

- the ability of the economy to function in extended reproduction mode; 
- maintaining state control over strategic resources, preventing their extensive outflow that could harm the national interests of the state;

- elimination of dependence of the economy on the import of the most important types of production, which can be produced at the required level in the country;

- maintaining an acceptable standard of living, preventing poverty rates, property differentiation of the population and unemployment beyond the limits, possible considering socio-political stability in society;

- stability of the financial system, banking system and national currency;

- the proper level of development of the Ukrainian financial and securities markets;

- reduction and effective management of external and internal debt;

- providing financial conditions for activation of investment activity;

- preservation of a single economic space and developed interregional economic relations, ensuring the observance of national interests.

In today's conditions, it is of particular importance to ensure the economic security of Ukraine for its regions, industries and business entities. In doing so, national security must be viewed, on the one hand, as a condition of the state, enabling it to protect the vital interests of the individual, society and the state from internal and external threats, while preserving its integrity and status, on the other, as a preventive system for a timely crisis prevention.

The current state of the management system is characterized by the absence of a sectoral hierarchy, but this in no way limits the use of economic security mechanisms. In addition, the industry is a collection of independent and independent economic entities, which requires detailing the specifics and specifics of their spheres of activity in the economic space of the country and the region, as well as while identifying threats to economic security. It should also be borne in mind that the interests of economic operators generally need to address their own security in the short, medium and long term, although this is indirect but concerns the economic security of both the regions and the country as a whole.

Regardless of the level of concentration of property, the economic entity must be an element of the set of participants in economic relations, and in this regard, its economic interests are intertwined with regional and state ones and should be taken into account when identifying threats, taking into account industry specificities.

It should be pointed out that the level of concentration of property in modern Ukraine has led to the creation of a mesoeconomics of the country of «oligarchic» type with a significant prevalence of holding structures in it. The corporate nature of management limits the ability of regions to regulate the activities of such companies, holdings with corporate privileges. The loss 
of control over the regional economy is also associated with the free movement of financial resources, with their concentration in large centers of the economy. In this respect, the security of the regions is closely intertwined with the sectoral one, and the extent to which their economic and social interests coincide significantly influences the likelihood of obstacles and threats.

The tasks of regional and sectoral institutes and structures to ensure economic security include not only combating the offenses of fiscal legislation, detecting, preventing and ending violations of monetary and financial legislation, but also ensuring compliance with laws, regulating relations in the fields of business and other economic activity as well as property relationships.

In modern conditions, the regions of Ukraine have developed as integral economic systems with their own peculiarities and economic policy, as well as independence in the choice of economic development strategy. The formation of a regional economic security system should be based on the substantiation of the system of economic interests of the region, interaction with industry and corporate structures, and virtually results from the system of national economic interests.

One of the aspects of the study of economic security issues and peculiarities of its provision at the regional level involves preservation of the administrative structure of the state. It is not always taken into account that there exists heterogeneity of problems solved at different levels of the economic system of the country, and a significant raw material orientation of the Ukrainian economy in terms of exhaustion and non-renewability of natural resources. In particular, T.Yu. Feofilova notes that the economic security of the country is a state of the economy, which in the conditions of limited natural resource potential and even under the influence of negative factors allows the state authorities and local selfgovernment bodies to perform their functions and to meet the needs of society, without undermining the state foundations and without threatening its sovereignty ${ }^{1}$.

The economic interests of the region are, first and foremost, the effective use of production potential and natural resources while ensuring favorable living conditions and social conditions of the population. Sectoral interests have similar priorities, but they are based on ensuring competitiveness through innovative development. Based on the interests of the region and the industry, an appropriate regional-sectoral strategy should be formed. In order to ensure economic security, it is necessary to involve an institutional mechanism for activating economic growth and competitiveness of the

\footnotetext{
${ }^{1}$ Feofilova T.Yu. (2009), “Osnovni katehorii teorii ekonomichnoi bezpeky”, Ekonomika ta upravlinnia, vol. 8 (46), pp. 22-25.
} 
economy as factors that make potential threats impossible. Competition is a key institutional framework for building a new paradigm of social development and building up a new social order.

The economy of an entity is dependent on political and social decisions made. Studying these circumstances makes it possible to understand the composition of institutional changes, which include a set of legal and economic management methods and help to identify threats in the economic sphere. An effective institutional system, pursuing public interests, organizes and harmonizes them in the pursuit of higher-level national interests, including national security ${ }^{2}$. This achieves the efficiency and unity of social development of the country in terms of modernization of its economy.

In the transition to an innovative and post-industrial economy, the basis of national security is a new quality of economic growth, in which scarce and non-reproducible natural resources are replaced by the effective use of scientific development. In the scientific sources there are 5 basic levels of the structure of the economy and its economic security: mega, macro, micro, mini and meso. Economic security is seen as a multilevel and multifactorial system for ensuring threats against all interacting levels of sectoral, intersectoral (corporate), territorial complexes, enterprises, as well as their subdivisions and employees.

Therefore, when considering economic security, several levels should be distinguished, namely:

1) economic security of the state, i.e. macroeconomic level;

2) economic security of the region, i.e. mesoeconomic level;

3) economic security of market agents (enterprises, organizations, institutions), ie microeconomic level;

4) economic security of households, ie nanoeconomic (basic) level.

The analysis of publications in the scientific literature has made it possible to identify three features that allow to classify approaches to the definition of the economic security level: sectoral affiliation (sectoral security); level of concentration of property (security of corporate structures); administrative and territorial structure (regional security).

The special role of meso levels is that they act as buffers in activating stability threats for the main levels of the economic system and serve as reserves in the event of an excess or shortage of factors, resources and conditions for sustainable development ${ }^{3}$.

Economic security, which determines the sustainable development of all levels of the economy, according to institutional theory, is associated with

\footnotetext{
${ }^{2}$ Tatarkyn A. T. (2006), "Ekonomichna bezpeka rehioniv - u iednosti teorii, metodolohii j praktyky", Ekonomika j keruvannia, vol. 4, pp. 28, 29.

${ }^{3}$ Holovchenko O.M. (2008), "Ekonomichna bezpeka rehionu v harantuvannia stabil'nosti natsional'noi ekonomiky”, [Ekonomichna bezpeka], Naukova dumka, Odesa, Ukrain.
} 
the establishment and functioning of organizational structures, laws and rules of conduct that ensure effective participation in globalization and informatization of the economy, innovation and business activity. Particularly important is the development of safeguards to prevent and minimize potential threats. The basis of such a mechanism can be the following criteria: the degree of activity in the formation of protection, the accuracy and completeness of the information field, the nature of the dangers, the system of monitoring the obstacles, the result of protection (avoidance of threats, achieving sustainable development).

The security strategy is the basis of a long-term strategy for the socioeconomic development of the country, not the other way around. In our view, a long-term strategy cannot be formulated without defining the national interests of the country. They express the substance of the essence of the country, sovereignty and its main characteristics in the world geopolitical space.

Regarding the organizational aspect of the security strategy, it is worth noting that there is a weak coordination in the economic and social spheres of our decisions. The market, of course, solves this problem, but only partially. It is necessary to ensure the unity of the management system in solving strategic goals, to balance the parameters of sustainable development with the existing and potential threats. A governing body is required to determine, on a scientific basis, the available resources, assess the potential of the national economic complex and the capabilities of science, and establish a system of natural and value balances. On this basis, it is possible to build a comprehensive strategy for the long-term development of the country, regions, industries, enterprises and households.

\section{Features of construction and its role in the construction of economic security systems}

Construction is a separate independent branch of the country's economy, which is intended for the introduction of new ones, as well as the expansion, reconstruction and technical re-equipment of existing objects of industrial and non-production purposes.

As a branch of material production, construction has a number of features that distinguish it from other industries. The peculiarities of the industry are explained by the nature of its final products, peculiar working conditions, peculiar properties of the technologies used, techniques, and methods of organization of the construction process and features of the construction production technology. As the technology of the construction process is quite complex, a mistake of even one worker can lead to accidents at the construction sites, as a result of which the company suffers considerable financial and material losses. 
Territorial remoteness of the construction sites from the locations of the contracting organizations complicates the management of the construction process, which has an impact on the increase of transport and material loss risks.

Time factor has a major impact on the technical and economic performance of the construction, as the construction of the construction site takes months or even years. Long duration of the construction process leads to the diversion of capital from circulation. Complexity of forecasting and planning the financial needs of a construction company, which may change during the construction process, such as changes in prices for construction materials, can cause an unforeseen suspension of the construction process and, as a consequence, lead to the loss of the image of the business entity and significant financial losses.

Construction is also characterized by certain peculiarities in staffing. Most construction workers, as a rule, are hired to perform a certain stage of work, which affects the lack of cohesion of the team, requires a greater attention to the coordination and management of personnel.

The wide variety of legal instruments in the field of construction law and the specifics of contracts for construction work lead to uncertainty in the understanding and interpretation of terms, and, as a consequence, to conflicts between participants in the construction process.

The activity of construction enterprises is regulated and controlled by the authorities. In order to begin the construction process, you must obtain a planning and construction approval from a number of services. Thus, the activity of a construction enterprise depends to a large extent on relations with the structures of state and local government. The authorities also establish or recommend pricing in the construction industry.

The general features of the entire industry, regardless of the objects being built and their purpose, include the following features:

1) variability, temporary nature, variety of construction production and nature of final products;

2) technological interconnection of all operations that are part of the construction process;

3 ) instable scope of construction works considering their complexity and types during the month;

4) participation of various organizations in the production of final construction products;

5) the role of climate and local conditions in construction works;

6) possibility of using construction products only at the place of production, i.e. its real estate; 
7) the services are provided not at the location of the construction enterprise, but at the site specified by the customer or at the location of the object;

8) long business cycle and low capital turnover;

9) high cost of construction objects, long duration of their operation;

10) the need to attract large amounts of resources, which explains the widespread practice of advance payments and one hundred percent subscription;

11) a high degree of individualization of the consumer (in most cases, the consumer of construction services is known until the time of construction of the construction object), which leads to the preliminary establishment of the contract price for the object or a specific mechanism for its determination;

12) availability of a large number of various information documents and the need to comply with the state requirements, norms and regulations;

13) high degree of opacity of procedures during licensing, obtaining permits.

Economic security of construction implies a state of efficient use of resources to prevent threats and ensure stable functioning.

The above features make it possible to determine the content of the main external and internal threats to the economic security of construction and determine the specifics of their management. As far as the external environment is concerned we can distinguish the following:

- crisis of the national economy;

- political instability;

- development of the shadow sector in the construction sector;

- imperfection of current legislation;

- high inflation;

- change in the exchange rate;

- high level of credit rates;

- reduction of quantity and quality of labor resources;

- low purchasing power of the population;

- weak technical regulation;

- imperfect competition;

- lack of investments and quality domestic building materials;

- energy dependence on other countries;

- force majeure (natural disasters, military conflicts, etc.);

- improper performance of contracts;

- irregular supply;

- high level of prices;

- delay in payment for work performed;

- breach of contractual relations.

Internal threats include the following: 
- ambiguity of goals;

- risky financing policy;

- inefficient management of assets and capital;

- low qualification of management personnel;

- seasonal fluctuations in construction;

- depreciation of fixed assets of most enterprises in the construction industry;

- simple equipment;

- increasing the level of turnover;

- work in difficult hazardous conditions, etc.;

- lack or superficial attitude to the marketing strategy;

- reducing the quality of human resources and efficiency of its use;

- significant working capital turnover period;

- wrong sales policy;

- low competitiveness of products.

Lack of stability of economic development of enterprises, a significant level of dependence on different types of threats and dangers, cases of unfair competition, fictitious entrepreneurship, raider attacks, necessitate the solution of issues for the further development of the construction industry of the country, creation of a reliable and effective system of financial security of construction enterprises in Ukraine.

Creating an economic security system and managing it effectively are necessary in order to counter and combat all kinds of threats and dangers.

Thus, in the development of the construction economic security system one should to take into account the specifics of construction activity and the above mentioned threats to the normal functioning and development.

The purpose of building a system of economic security for construction is to protect against external and internal threats to ensure stable functioning and financial and economic growth.

According to the purpose, the main tasks of the financial and economic security system should be the following:

1) timely identification of possible threats to economic security and taking measures to prevent them;

2) eliminating real internal and external threats to economic security;

3) ensuring the economic efficiency of the construction activity, its financial stability and independence;

4) ensuring the preservation of property and information security of construction enterprises at all stages of the construction process;

5 ) ensuring personnel security, which includes not only the selection of highly qualified employees, but also the formation of a training system for the industry, their certification, the organization of safe working conditions and personal safety; 
6) protection of commercial secrets by restricting access to trade secret information;

7) protection of interests of construction enterprises in cooperation with partners and local authorities and creation of a system of protection against raider attacks.

The main threats to economic security include:

- insufficient use of opportunities for Ukrainian companies to enter international capital and technology markets, since the quality of products is lower than international standards;

- mismatch of the motives of TNCs investment activity to the needs of structural restructuring of Ukraine. Of course, TNC owners are the main motive behind the multiplication of their profits and are almost in no way interested in developing a strong Ukrainian economy. This is explained by the reluctance to obtain in the future an additional competitor in the market for the sale of products and the purchase of production resources;

- monopolization of strategic industries. Artificially created barriers to increasing sectoral competition in all types of economic activities;

- lack of a comprehensive economic security strategy that needs to be developed to develop a sustainable development trajectory for Ukraine over the long term;

- limited access to financial, technical, technological and information resources;

- lack of effective mechanisms for transformation of temporarily free funds of individuals and legal entities into investments;

- regional and sectoral disparities in the investment of capital in its various forms. In particular, due to the uneven economic development and investment attractiveness, regional and sectoral disparities may arise in the investment flow;

- the deterioration of the investment climate caused by the occupation of the Autonomous Republic of Crimea, military actions in the East of the country, the consequences of the economic depression and uncertain prospects for economic growth, as well as issues of increasing the level of corruption, slowing down reforms and reducing the capacity and predictability of the state policy. This forced private companies to refuse or delay the implementation of investment projects for future periods ${ }^{4}$;

- lack of state support for the financial stabilization of the construction industry, which is perhaps the most important in the context of the ongoing study of the threat to national economic security. The catastrophic loss of the industry has already led to the negative total value of construction capital. In

${ }^{4}$ Ekonomichna ta may̆nova bezpeka pidpryiemstva i pidpryiemnytstva. Antyrey̆derstvo. B.M. Andrushkiv, Yu.Ia. Vovk, P.D. Dudkin ets. - Ternopil: Terno-hraf, 2008. 424 p. 
the future, this threatens to exit a large number of contracting companies and further reduce construction products, works and services. Therefore, the drastic consequence of this threat will be a further decrease of production capacities, the level of providing the population with quality trade facilities, transport infrastructure, and socio-cultural sphere.

In view of these threats, the task of creating a system of monitoring, analyzing and assessing economic security at the levels of the national economy, construction industry and regions, which underpins the model of system dynamics of development, becomes especially relevant. For this purpose economic security indicators and their limit values are used. Limit values are end values, the excess of which impedes the normal development of various components of the economic system, leads to the formation of negative, destructive tendencies in the field of economic security. Examples of internal threat indicators include the depreciation of fixed assets, the unemployment rate, the differentiation of household incomes, and the inflation rate. Their approximation to the maximum permissible (limit) value indicates an increase in threats to the economic stability of the society, and exceeding the limit values - a transition of society into a zone of instability and social conflicts, when economic security may be undermined. Indicators of external threats include the maximum permissible level of public debt, maintaining or losing positions in the world market, the dependence of the economy and its major sectors on imports of foreign products and raw materials. Obtaining limit values of economic security indicators is connected with the fundamental determination of national priorities of the country.

Indicators of particular importance are the following: gross national product - the market value of final goods and services produced in the country's economy over a specified period of time (year); rates of structural deformation of production and society. We should also highlight the following indicators of economic security: the coverage of imports by exports, export dependence, import dependence, the volume of outstanding on a specific date of loans made by the state in domestic and foreign loan markets, the budget deficit is excess of the budget revenues over the amount of the budget expenditure, the level of economy monetization, which is defined as a percentage as a ratio of money supply to annual GDP.

The most important macroeconomic and social indicators at the regional level are: 1) GRP dynamics, indicators of volumes, rates and structure of industrial production, investments, share of exports in production; 2) the state of the natural resource, production and scientific and technical potential of the region; 3) the ability of the economic mechanism to adapt to changes in internal and external factors (inflation, budget deficits, external economic conditions, debt, savings); 4) quality of life of the population (GRP per 
capita), unemployment rate and socio-demographic differentiation of incomes, average life expectancy.

Such macroeconomic indicators characterize the conditions of existence of the economic system of the country, industry, and region.

\section{CONCLUSIONS}

Thus, in order to design a risk minimization system as an element of economic security, it is necessary to select the most significant economic security indicators, determine and justify the limits of the selected indicators. It is necessary to establish a system of indicators and predicators for construction and to monitor them at the state, local government or selfregulatory level.

The formation of a model of system dynamics of the construction industry may increase the number of economic security indicators. It is also acceptable to form a single, generalized optimization parameter as a function of value, in which all indicators of economic security of construction will be reflected.

\section{SUMMARY}

The article reviews theoretical approaches to the formation of the economic security system at the macro micro and noneconomic levels of the economy. The author analyzes theoretical and practical preconditions for the formation of strategic aspects of economic security as a basis for the development of the economic system. At the same time, national security is viewed on the one hand as a condition of the state, enabling it to protect the vital interests of the individual, society and the state from internal and external threats, while maintaining its integrity and status, on the other, as a preventive system for early warning of the crisis. It is determined that the security strategy is the basis of the long-term strategy of socio-economic development of the country, not the other way around.

It is revealed that the level of concentration of property in modern Ukraine has led to the creation of mesoeconomics of the country of «oligarchic» type with a significant prevalence of holding structures in it. The corporate nature of management limits the ability of regions to regulate the activities of such companies, holdings with corporate privileges. Loss of control over the regional economy is also associated with free movement of financial resources, with their concentration in large centers of influence.

The author defines mesolevels as buffers in activating stability threats for the basic levels of the economic system serving as reserves in case of excess or lack of factors, resources and conditions for sustainable development.

The article gives the analysis of construction features including the nature of its final products, peculiar working conditions, the application of 
different technologies, techniques, and methods of organization of the construction process in the construction of each individual object, the territorial distance of the construction objects from the locations of contracting organizations, the considerable duration of the process, the complexity of forecasting and planning the financial needs of a construction company, which may change throughout the construction process, and its role in building a system of economic security.

It is argued that formation of the construction economic security system must take into account the specifics of the construction activity and the above threats to normal functioning and development, and the purpose of construction economic security system is to protect against external and internal threats to ensure stable functioning and economic growth.

This requires the establishment of a system for monitoring, analysis and evaluation of economic security at the levels of the national economy, construction industry and regions, as well as a system of indicators of economic security of construction and calculation of their limit values.

\section{REFERENCES}

1. Abalkyn L.Y. (1994), "Ekonomycheskaia bezopasnost' Rossyy: uhrozy y ykh otrazhenye",Voprosy ekonomyky, vol. 12, pp. 12.

2. Holovchenko O.M. (2008), "Ekonomichna bezpeka rehionu v harantuvannia stabil'nosti natsional'noi ekonomiky", [Ekonomichna bezpeka], Naukova dumka, Odesa, Ukraine.

3. Holubtsiv A. N. (2005), "Ekonomichna bezpeka rehioniv PFO", Pytannia statystyky, vol. 4, pp. 52-53.

4. Zhalilo Ya.A. (2003), "Ekonomichna stratehiia derzhavy: teoriia, metodolohiia, praktyka", [Ekonomichna stratehiia], Naukova dumka, Kyiv, Ukraine.

5. Shevchenko, L. S. Hrytsenko, O. A. and Makukha S. M. (2009), "Ekonomichna bezpeka derzhavy: sutnist' ta napriamy formuvannia", [Ekonomichna bezpeka], Naukova dumka, Kyiv, Ukraine.

6. Inshakova O.I. (2004), "Stalyj rozvytok krain SND: teoretychna kharakterystyka j systema indykatoriv", Visnyk S.-Peterb. un-ta., vol. 1.

7. Pasternak-Taranuschenko H. A. (1994), "Ekonomichna bezpeka derzhavy" [Ekonomichna bezpeka], Naukova dumka, Kyiv, Ukraine.

8. Tatarkyn, A.Y.. Kuklyn, A.A and Myzyn, A.L. (2009), "Monytorynh ekonomycheskoj bezopasnosty rehyonov kak uslovye stabyl'noho razvytyia" [Ekonomichna bezpeka], Naukova dumka, Ekaterynburh, Russia.

9. Olejnykov E. A. (2005), "Ekonomichna j natsional'na bezpeka", [Ekonomichna bezpeka], Naukova dumka, Kyiv, Ukraine.

10. Stepanenko A. (2002), "Otsinka ekonomichnoi bezpeky Ukrainy ta ii rehioniv", Rehional'na ekonomika, vol. 2, pp. 39-54. 
11. Tatarkyn A. T. (2006), "Ekonomichna bezpeka rehioniv - u iednosti teorii, metodolohii j praktyky", Ekonomika j keruvannia, vol. 4, pp. 28, 29.

12. Feofilova T.Yu. (2009), "Osnovni katehorii teorii ekonomichnoi bezpeky", Ekonomika ta upravlinnia, vol. 8 (46), pp. 22-25.

13. Ryzhakova G. Implementation of principles of biospheric compatibility in the practice of ecological construction in Ukraine [Tекст] / D. Chernyshev, I. Ivakhnenko, G. Ryzhakova, K. Predun // International Journal of Engineering \& Technology - UAE: Science Publishing Corporation, 2018 - Vol 10, No 3.2: Special Issue 2 - pp. 584-586.

14. Tetyana Marchuk, Dmytro Ryzhakov, Galyna Ryzhakova and Sergiy Stetsenko (2017). Identification of the basic elements of the innovationanalytical platform for energy efficiency in project financing. Investment Management and Financial Innovations Vol. 14(4), pp. 12-20.

15. Avdyiskyi, V.I. and Bauer, V.P. (2010) Ekonomichna bezpeka v systemi transformatsii svitovoi finansovoi arkhitektury, Efektyvne antykryzove upravlinnia. № 1. PP. 42-48.

16. Sorokina, L.V. and Goiko, A.F. (2016) Doslidzhennia zahroz investytsiinoi bezpeky budivelnykh pidpryiemstv, Budivelne vyrobnytstvo. V. 61. PP. 9-20.

17. Bielienkova O. Yu. Tendentsii rozvytku budivelnoi haluzi yak chynnyky formuvannia stratehichnoi konkurentospromozhnosti budivelnykh pidpryiemstv // Budivelne vyrobnytstvo. 2014. Vol. 57. P. 24-30.

18. Fedosova, O.V. Molodid, O. O. and Terenchuk, S. A. (2011) Vyznachennia rivnia ekonomichnoi bezpeky budivelnoho pidpryiemstva na osnovi ekonometrychnykh modelei, Upravlinnia rozvytkom skladnykh system. V. 5. - PP. 117-119.

19. Kushniruk, A. O. (2012) Pidkhody do otsinky ekonomichnoi bezpeky budivelnoho pidpryiemstva / Budivelne vyrobnytstvo. № 54. Pp. 77-81.

20. Mihus, I. P. and Laptiev, S. M. (2011) Rol sluzhby ekonomichnoi bezpeky aktsionernoho tovarystva u zabezpechenni yoho ekonomichnoi bezpeky. Ekonomika ta derzhava. N 12. PP. 15-17.

21. Vakhovych, I. V. (2015) Pidvyshchennia efektyvnosti upravlinnia biznes-protsesamy budivelnykh pidpryiemstv. № 59. PP. 3-6.

22. Zeltser, R.Ya., Bielienkova, O.Yu. and Dubinin, D.V. (2018) Innovatsiini modeli i metody orhanizatsii, upravlinnia i ekonomichnoi otsinky tekhnolohichnykh protsesiv budivelnoho vyrobnytstva Kyiv: «MP Lesia». 209 p.

23. Zeltser, R.Ya., Bielienkova, O.Yu., Novak, Ye., Dubinin D.V. (2019) Digital Transformation of Resource Logistics and Organizational and Structural Support of Construction. Nauka i innovatsii. V 15(5), pp. 38-51. 
24. Tytok, V. V. (2013) Formuvannia modeli zhytlovoho budivnytstva v misti. Shliakhy pidvyshchennia efektyvnosti budivnytstva $v$ umovakh formuvannia rynkovykh vidnosyn. V. 30. PP. 90-99.

25. Tymoshenko, O. V. (2019) Vyklyky ta zahrozy chetvertoi promyslovoi revoliutsii: naslidky dlia Ukrainy. Biznes Inform. Vol. 2. Pp. 21-29.

26. Ekonometrychnyi instrumentarii upravlinnia finansovoiu bezpekoiu budivelnoho pidpryiemstva : [monohr.] / za nauk. red. d.e.n., prof. L. V. Sorokinoi. - K. : Kyivskyi natsionalnyi universytet budivnytstva i arkhitektury; Kryvyi Rih : Vyd. FOP Cherniavskyi D. O., 2017. - C. 4-26.

27. Izmailova K.V., Bielienkova O.Iu., Moholivets A.A. (2019) Sutnist ekonomichnykh tsykliv ta yikh vplyv na ekonomichnu stiikist budivnytstva. Naukovi pratsi NDFI. 2019. № 2. PP. 139-150.

28. Tytok, V. V. (2012) Suchasnyi stan protsedury otrymannia zamovnykom budivnytstva dozvilnykh dokumentiv. Shliakhy pidvyshchennia efektyvnosti budivnytstva $v$ umovakh formuvannia rynkovykh vidnosyn. Vol. 28. P. 142-150.

\section{Information about the author:}

Stetsenko S. P.,

DSc in Economics, Associate Professor, Head of the Department of Construction Economics, Kyiv National University of Construction and Architecture (KNUCA) 31, Povitroflotsky ave., Kyiv, 03037, Ukraine 